\title{
Education for Citizens in the New Era: Challenges and Opportunities in Realizing Constitutional Rights
}

\author{
Sjamsi Pasandaran ${ }^{1, *}$ Deitje Adolfien Katuuk ${ }^{2}$ \\ ${ }^{I}$ Pancasila and Civic Education Departement, Universitas Negeri Manado, Tondano, Indonesia \\ ${ }^{2}$ Educational Management, Universitas Negeri Manado, Tondano, Indonesia \\ ${ }^{*}$ Corresponding author.Email: spasandaran@unima.ac.id
}

\begin{abstract}
This study examines the challenges and problems in the context of fulfilling the constitutional rights of citizens' education in the new era. The purpose of this study is to identify challenges and opportunities as well as efforts to develop education for citizens in fulfilling their constitutional rights to obtain good and quality education. The theoretical preposition of this study is that every citizen has constitutional rights in the field of education; and the fulfillment of this constitutional right is the obligation of the state and government to make it happen. Using a descriptive analytic survey method, this study was conducted on students in both primary and secondary schools. Data processing and analysis is carried out using analytical descriptive. The research findings show that the new era provides new educational challenges for citizens. These new challenges are the fulfillment of the right to quality learning of every citizen, the reconstruction and revitalization of the values that have developed in the new era. The next challenge is related to the strategy of developing education for citizens, both pedagogical concepts and learning strategies. There are opportunities that can be exploited, namely the development of information and communication technology that allows a paradigm shift from traditional learning to virtual-based learning. . Several important things were recommended, namely the need for policies that encourage the involvement of all citizens of learning age, strengthening the development of values in the learning process, and the need for the development of a new paradigm in learning for citizens.
\end{abstract}

Keywords: Constitutional rights, new era, quality education.

\section{INTRODUCTION}

Every country globally is currently faced with a severe Education is the constitutional right of every citizen. Indonesia regulates these constitutional rights in the 1945 Constitution, particularly in Article 31 paragraph (1) that every citizen has the right to education. Sebastian Edwards through his research found that every country stipulates in its constitution that education is a constitutional right of every citizen [1]. The implication of this constitutional right is that the state and government have a constitutional obligation to fulfill the right of every citizen to obtain education. The government has an obligation to ensure that every school-age population gets an education. Jody Heymann through his research found that to fulfill these constitutional rights, many countries implement compulsory education programs, namely compulsory basic education and compulsory secondary education [2]. Jody Heymann sees that the constitutional rights of citizens in obtaining education are closely related to the policies of every government. Rij Mastry researched that racial policy issues can be important issues in fulfilling citizens' human rights in obtaining education [3]. Ridwan Purnama found the importance of the juridical management aspect in fulfilling the right to education by every citizen [4].
These studies have not specifically examined the effects of special situations or extraordinary situations such as war situations, natural disasters and or pandemic situations. Thomas Smith specifically examines the public's response to the fulfillment of human rights during the Covic19 pandemic. Thomas Smith examined constitutional limitations, both specific and general, that limit the fulfillment of the human rights of every citizen to obtain education in the COVID-19 pandemic situation. It was found that there are fundamental constitutional problems, namely the problem of limiting educational activities and the issue of constitutional obligations to guarantee, among others, the occurrence of restrictions. health of every citizen. The era of the covid-19 pandemic has apparently limited academic activities for lecturers, students and researchers. [5]. Jaime Saavedra reports that more than 1.6 million school children have lost their right to learn [6]. The condition of the COVID-19 pandemic turned out to be very influential on children in obtaining the right to education and quality learning processes.

The results of the research and studies mentioned above show that the focus of the study is on issues that affect the fulfillment of citizens' constitutional rights in obtaining education. These problems are political problems and educational policies by the government, education management problems, and extra ordinary situations such as 
natural disasters and pandemic problems including the covid-19 pandemic. The research and study of this article is focused on efforts to fulfill the constitutional rights of education in extra-ordinary situations, especially in the COVID-19 pandemic situation. namely how to develop educational praxis in a new era in the covid pandemic situation. The educational praxis includes the reconceptualization of education and quality learning practices. It is important to study that the extraordinary situation of the COVID-19 pandemic has given rise to a new situation called a new era. This new era demands and requires academically it is necessary to study relevant and quality educational concepts and practices so that the constitutional rights of every citizen can be fulfilled.

\section{THEORETICAL REVIEW}

In this study it is understood that the fulfillment of the constitutional right to obtain quality education is the fulfillment of human rights [7], so it is the obligation of every state and government to fulfill these rights. In extraordinary situations, the fulfillment of these rights is driven by the demands of global learning in the new era [8], the development of digital education for children from primary education to higher education [9]. In some countries, independent schools have been developed which include the main elements of learning such as teachers, curriculum, assessment, and learning processes [10]. In facing the new era, the OECD emphasizes that it is important to equip children with competencies consisting of knowledge, attitudes, values and skills. These competencies give children the ability to create new values, reconciling tensions and dilemmas, taking responsibilities, and transforming competencies [11]. The Council of Europe puts forward the competencies needed by every citizen that can be used in extraordinary situations that include values such as respect for human rights, a responsible attitude to life together, participation and critical thinking skills [12].

\section{METHODS}

This research and study uses analytical descriptive methods, namely examining challenges, pedagogical concepts and learning models in fulfilling the right to obtain quality education at 6 (six) public high schools in Manado City. Observations and analysis of the learning design and learning practices were carried out. Observations and analysis were carried out on the preparation of the Learning Implementation Plan (RPP), and the consistency of the learning process with the RPP. Identified aspects of the content and practice of learning and their compliance with the principles of quality standards of learning content and standards of the learning process. Data analysis was carried out qualitatively by calculating the tendency to comply with the established standard principles.

\section{RESULTS AND DISCUSSION}

The results of the study show important aspects of learning content and practice that are challenges in fulfilling citizens' rights to obtain quality education. These challenges are that the content and practice of learning have not been supported by a clear and strong foundation and conceptual and practical design for learning. The design and practice of learning have not yet characterized the pedagogical principles that are relevant to the demands of learning in the new era. The pedagogical transformation has not been carried out properly. Learning has not been developed holistically, the development of critical thinking and creative thinking is still trapped in the directive teaching process, value transforming is still in the transmission of highly cognitive values, and the dialogue process in the form of various projects and activities has not yet appeared in the design and learning process. The findings of this study indicate that political policies regarding efforts to fulfill the constitutional rights of citizens' education are not sufficient to only include increasing the level of quantity of the main indicators of education such as increasing the participation rate of citizens in obtaining education, or the length of education obtained. Another important aspect of fulfilling constitutional rights is equal distribution of quality. Fulfillment of this quality aspect is very important, in preparing children to be able to face future challenges that really require quality, professionalism, and selfcapacity. The basic meaning in the effort to fulfill this quality aspect is the fulfillment of citizens' constitutional rights regarding quality education.

\section{CONCLUSION}

Based on the results and discussion presented above, it can be concluded that the fulfillment of citizens' constitutional rights to obtain quality education faces challenges related to the reconceptualization of pedagogical approaches towards transformative pedagogy. The reconceptualization of this educational approach needs to be followed by an increase in the quality of the learning process. From these conclusions, it is recommended the need for strengthening human resources, especially teachers, both through pre-service education and in-service education in the form of education and exercises that are carried out on an ongoing basis.

\section{AUTHORS' CONTRIBUTIONS}

Pasandaran: Conceptualization, design, analysis, material support, providing final approval. Katuuk: data interpretation, statistical analysis, writing, revising the manuscript.

\section{ACKNOWLEDGMENTS}

Thank you to the team, who has supported this research. We also thank all those who have helped in completing this paper.

\section{REFERENCES}

[1]. Edwards, S., \& Marin, A. G. (2014). Constitutional Rights and Education: An International Comparative Study. National Bureau of Economic Research. https://doi.org/10.3386/w20475 
[2]. Heymann, J., Raub, A., \& Cassola, A. (2014). Constitutional rights to education and their relationship to national policy and school enrolment. International Journal of Educational Development, 39, 131-141. https://doi.org/10.1016/j.ijedudev.2014.08.005

[3]. Mestry, R. (2017). A critical analysis of the learners' constitutional rights to basic education in South African public schools. Koers, 82(3), 1-12. https://doi.org/10.19108/KOERS.82.3.2327

[4]. Purnama, R., Budimansyah, D., \& Ruyadi, Y. (2016). Higher Education Management and Operations in Fulfilling Citizen's Education Rights. 15(3), 978-984. https://doi.org/10.2991/gcbme-16.2016.181

[5]. Schmitz, T. (2020). COVID-19 Response and Human Rights - Comments From the German and European Perspective. 499(Icolgas), 727-735. https://doi.org/10.2991/assehr.k.201209.357

[6]. Saavedra, J. (2020). Educational challenges and opportunities of the Coronavirus (COVID-19) pandemic. World Bank Blogs. https://blogs.worldbank.org/education/educationalchallenges-and-opportunities-covid-19-pandemic.
[7]. The Law Library of Congress. (2016). Constitutional Right to an Education in Selected Countries (Vol. 6462, Issue May). http://www.law.gov

[8]. Ramaley, J. (2020). Global Learning in a New Era. Global Learning in a New Era, 6.

[9]. Chorosova, O. M., Solomonova, G. S., \& Struchkov, V. G. (2020). Prospects for the Development of Digital Educational Environment in North-Eastern Federal University in the Context of Adult Education. Proceedings of the International Scientific Conference "Far East Con" (ISCFEC 2020), 128 (Iscfec), 27382743. https://doi.org/10.2991/aebmr.k.200312.388

[10]. Brewer, D. J. (2007). Education For A New Era. Early Education, March 2017.

[11]. OECD. (2018). The Future of Education and Skills: Education 2030. OECD Education Working Papers, 123. http://www.oecd.org/education/2030/E2030 Position Paper (05.04.2018).pdf.

[12]. Richardson, J., \& Milovidov, E. (2019). Digital citizenship education handbook: Being online, wellbeing online, and rights online. 